\title{
Når klimaet bryder mønstret - naturlige og menneskeskabte cendringer
}

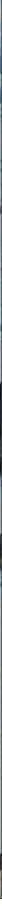

Kan man skelne mellem naturlige og menneskeskabte klimacendringer? (Foto: Jacob C. Yde, Center for Geomikrobiologi; Sydøstgrønland, 2006)

Af Marit-Solveig Seidenkrantz, Centre for Past Climate Studies, Geologisk Institut, Aarhus Universitet, Antoon Kuijpers, GEUS, og Torben Schmith, DMI.

Ved at sammenligne geologiske undersøgelser med moderne vejrdata mener vi nu at kunne skelne mellem naturlige variationer i klimaet og menneskeskabte klimaændringer. Resultaterne peger på, at de sidste 20-30 års opvarmning ikke kan forklares af naturlige processer.

I denne tid hører vi den ene dommedagsprofeti om menneskeskabte klimaforandringer efter den anden. Men der også røster ude, som bestrider, at vi mennesker overhovedet har indflydelse på klimaet. Debatten udvikler sig til tider i retning af en skyttegravskrig, hvor nuancer ikke er tilladte. Derfor er der behov for bedre at kunne skelne mellem naturlige og menneskeskabte klimaforandringer.

Gennem sammenligning af geologiske undersøgelser af fortidens klima og moderne vejrdata er dette lykkedes. Disse undersøgelser tyder på, at skønt en ikke ubetydelig del af det 20. århundredes opvarmning antageligt skyldes naturlige variationer, kan den betydelige globale opvarmning, der er sket gennem de sidste 20-30 år, ikke alene forklares ved naturlige processer.

Faktisk tyder meget på, at klimasystemet er

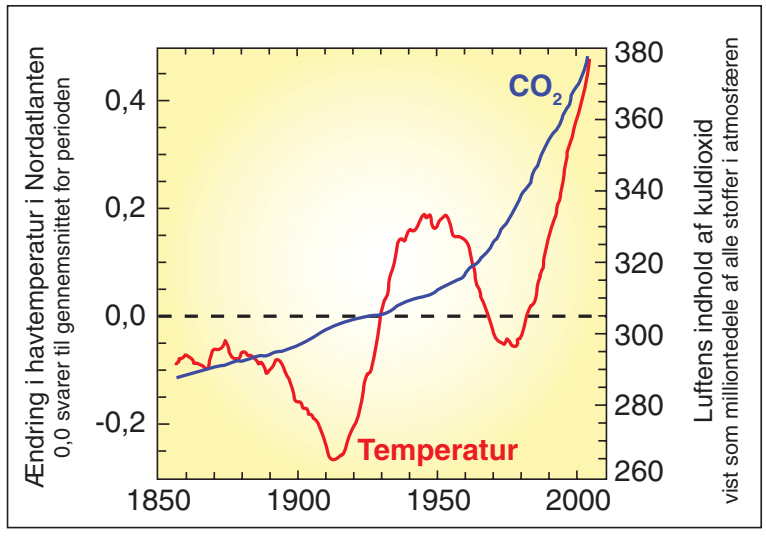

Havtemperaturen i Nordatlanten sammenlignet med atmosfarens indhold af $\mathrm{CO}_{2}$ siden 1856. (Grafik: UVH modificeret efter Torben Schmith og oprindeligt Kaplan et al. 1998, J. Geophys. Res. 103) i gang med at gennemgå en grundlæggende forandring.

Mere end én forklaring på klimaændringer I den løbende debat om betydningen af den igangværende klimaforandring, begrænses diskussionen oftest til en sammenligning med klimaudviklingen over de sidste 100150 år. Dette skyldes, at man først startede en systematisk indsamling af vejrdata (såsom temperatur, nedbør og trykforhold) i midten af 1800-tallet. Umiddelbart skulle man også tro, at 150 år er tid nok til at give et godt billede at, hvordan et "normalt" klima opfører sig. Men ofte bliver det glemt, at netop midten af 1800-tallet var tidspunktet for afslutningen af den såkaldte "Lille Istid", der var den koldeste periode, der har eksisteret over de sidste 6.000-8.000 år.

De sidste 150 år har den generelle, langsigtede tendens været en opvarmning, men der har også har været koldere perioder - senest i 1960'erne. Vi ved, at mængden af drivhusgasser i atmosfæren har stor betydning for klimaet. Der har tidligere i Jordens historie været perioder med meget store mængder af drivhusgasser i atmosfæren. Under disse perioder var der også normalt betydeligt varmere end i dag. Men hvis man sammenligner temperaturen for det 20. århundrede med mængden af $\mathrm{CO}_{2} \mathrm{i}$ atmosfæren (se figuren til venstre), kan man se, at der ikke er en direkte lineær sammenhæng. Dette betyder, at drivhusgasser ikke 

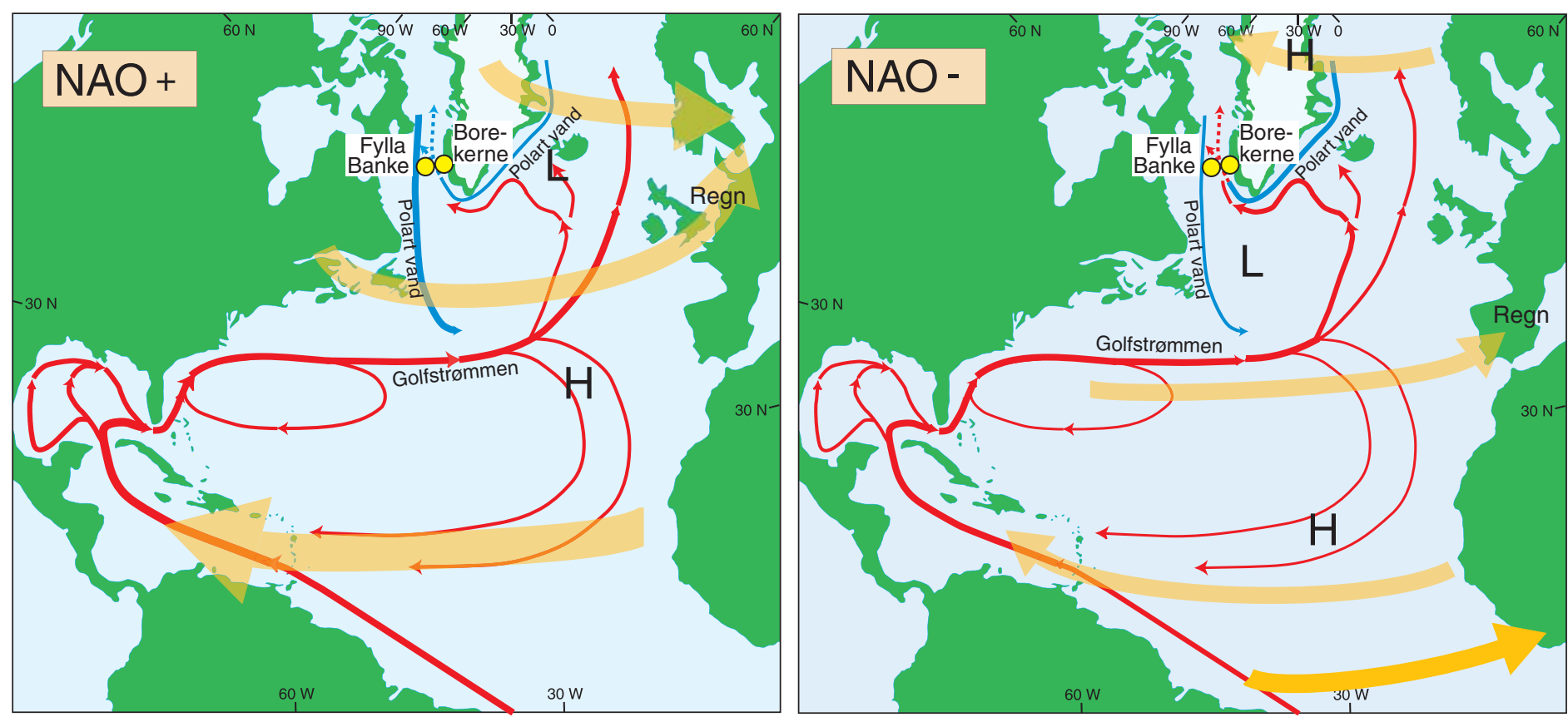

Havstrømme (røde pile = varmt vand; blå pile = koldt vand), vindretninger (gule pile) og placering af højtryk $(H)$ og lavtryk $(L) i$ Nordatlanten under NAO+ (til venstre) og NAO- (til højre). Den undersøgte borekerne ncer Nuuk og den oceanografiske målestation ved Fylla Banke er vist som gule pletter. (Grafik: Marit-Solveig Seidenkrantz)

nødvendigvist er den eneste forklaring på klimaforandringerne. Vi må derfor lede efter supplerende forklaringer.

\section{Betydelige variationer de sidste $\mathbf{2 . 0 0 0}$ år}

Hvis man vil kende til den mere langsigtede tendens for klimaet, må man ty til undersøgelser af fortiden gennem studiet af geologiske data. Specielt de sidste 2.000 år har vores klima været præget af betydelige variationer. De mest kendte fænomener, som også har sat deres præg på især den europæiske kulturhistorie, er Romersk Varmtid (ca. 500 f. $\mathrm{Kr}-400$ e.Kr.), den europæiske Mørke Middelalders Kuldeperiode (400700 e.Kr.), Middelalder Varmtid (800-1200 e.Kr.), Den Lille Istid (1350-1850 e.Kr.) og endeligt det 20. århundredes Moderne Opvarmning siden ca. 1850 (figur A øverst på side 32). Vores nuværende klimaforandring repræsenterer derfor ikke blot en simpel ændring fra et stabilt "normalt" klima, men skal også nærmere ses på baggrund af generelt ustabile klimaforhold, som har præget Jorden gennem de seneste årtusinder.

Kun ved at forstå processer, sammenhænge og tidsskalaer for disse klimavariationer er det muligt at forstå, hvordan og hvorfor klimaet forandrer sig i dag og i fremtiden. Et af de endnu til dels uløste spørgsmål er således at kunne skelne mellem naturlige klimavariationer og menneskeskabte påvirkninger. Ved at sammenligne geologiske data for Jordens historie med instrumentelle måledata er det lykkedes os at gøre et første skridt i denne retning.

\section{Den Nordatlantiske Oscillation}

Der er fremsat en række teorier til at forklare årsagen til den nuværende klimaændring. De strækker sig fra variationer i solens styrke, over svovlgasser fra vulkanudbrud, udledning af drivhusgasser og til storskala variationer i havcirkulationen. Det vil her gå for vidt at diskutere alle teorierne, så vi vil her blot fokusere på en af de vigtigste naturlige mekanismer: Den Nordatlantiske Oscillation.

"Alle Vintere i Grønland ere haarde, dog med Forskjel. De danske lægge Mærke til, at naar Vinteren har været streng, som vi kalde det, i Danmark, har den grønlandske på sin Maade været mildere, og omvendt". Dette citat stammer fra et dagbogsnotat af Hans Egede Saabye, som var missionær i Grønland i 1770-1778. Det er en af de ældste historiske kilder, som beretter om det modsatrettede temperaturmønster, der ses mellem Europa og Vestgrønland.

Dette i dag velkendte fænomen er til dels en konsekvens af den såkaldte Nordatlantiske Oscillation (NAO), som er en temperaturvippe, der påvirker både atmosfæren og havet. Det er grundlæggende styret af lufttrykket over Nordatlanten, hvor der under de såkaldte $\mathrm{NAO}+$ situationer er et kraftigt lavtryk over Island og et kraftigt højtryk over Azorerne. Denne trykforskel danner stærke vestenvinde, der fører varm luft til Danmark, specielt om vinteren. Vestenvinden presser desuden Golfstrømmens vand over mod Europas kyst (figuren ovenfor), mens kysten af Vestgrønland overvejende bades i koldt vand fra det Arktiske Ocean. Nogle år er forskellen i lufttrykket mindre, og vestenvinden bliver svagere (NAOsituationer). Golfstrømmen presses da i mindre grad over mod Europa, og en del af det varme vand vil søge mod vest og bringe varme til Vestgrønland. $\mathrm{NAO}+$ forårsager således milde vintre med megen nedbør i
Nordvesteuropa, men koldere vintre i Vestgrønland. Omvendt giver NAO- kolde og tørre vintre i Nordvesteuropa og varmere vintre i Vestgrønland.

Naturlige ændringer de sidste $\mathbf{2 . 0 0 0}$ år Resultater af undersøgelser af marine borekerner fra Vestgrønland viser, at der har været store variationer i mængden af varmt, atlantisk vand, der har nået området gennem de sidste 2.000 år. Sammenligninger af beregninger af luftens temperatur i Europa og andre dele af den nordlige halvkugle (figur A øverst på side 32) med estimater 
Istid). Disse nye forskningsresultater viser således, at disse store klimaforandringer, som har præget de sidste 2.000 år, i høj grad var forårsaget af ændringer i vindretninger og havstrømme.

Nyere forskning tyder på, at også andre mekanismer end NAO kan skabe variationer i Golfstrømmen. Uden at komme ind på detaljer involverer disse mekanismer interne variationer i den såkaldte thermohaline cirkulation, med ændringer af nedsynkningen af Atlanterhavsvand ved Grønland og Labrador. Disse ændringer kan have en varighed af flere hundrede år og derved skabe klimaændringer i lufttemperaturen af en tilsvarende længde. Også mekanismer såsom variationer i solens indstråling og El Niño Southern Oscillation synes at have spillet en rolle.

\section{Det 20. århundredes opvarmning}

Moderne målinger og geologiske data fra de sidste 2.000 år fortæller os altså, at klimaet både $\mathrm{i}$ fortid og nutid $\mathrm{i}$ høj grad er og har været præget af et kompliceret samspil mellem atmosfæriske forhold og havstrømmenes forløb. De instrumentelle målinger viser desuden, at der gennem det 20. århundrede er sket en ændring fra et klima domineret af $\mathrm{NAO}-$ til et mere $\mathrm{NAO}+$ domineret klima.
Det betyder, at en ikke uvæsentlig del af temperaturstigningen antageligt kan forklares gennem en naturlig ændring fra et klima domineret af svage vestenvinde og mindre transport af varme til Europa til et klima, der er præget af stærke vestenvinde og øget transport af varme til Europa.

De seneste årtier har Jordens klima dog undergået en endnu hurtigere ændring end tidligere. Den forståelse, som de geologiske data har givet os, kan bruges til at undersøge, om det system, der har virket i 2000 år, stadig er i kraft. Vi har derfor sammenlignet havvandstemperaturen i juni måned fra Fylla Banke ud fra Nuuk, Vestgrønland, med den gennemsnitlige luft-temperatur om vinteren i Nordvesteuropa for perioden 1950-2005 (figuren nederst på side 32). Begge kurver viser betydelige variationer. Indtil ca. 1985 var der et modsatrettet mønster mellem temperaturen i Europa og ved Vestgrønland; dog med en forskydning på 4-5 år, således at en klimaændring ved Vestgrønland først slog igennem i Europa efter 4-5 år. Denne forsinkelse skyldes antageligt den træghed, der er i systemet pga. havstrømmens langsomme bevægelse. Med andre ord kan vi sige, at indtil 1985 oplevede vi et klima, der overordnet set var styret at de samme principper, som vi har set over de sidste 2.000 år.

\section{Mennesket ændrer klimaet}

Efter 1985 er situationen dog tilsyneladende en anden. Selvom data fra Fylla Banke indikerer en række variationer i havcirkulationen, følger klimaet i Europa ikke længere det forventede mønster. Det er kendt, at den globale temperatur begyndte at stige betydeligt gennem de seneste årtier, og set som gennemsnit over hele perioden har de seneste tre årtier (efter 1973) antageligt været den varmeste periode gennem de seneste 500 år. Målinger af lufttrykket mellem Island og Azorerne tyder faktisk på, at vi for øjeblikket befinder os i en NAO- domineret situation, hvilket burde forårsage en afkøling; men alligevel er temperaturen i Europa steget. Samtidig har solen i de senere år udledt mindre energi end gennemsnitligt, så heller ikke ændringer i solens styrke kan alene forklare fænomenet. Dette betyder, at selvom en stor del af den temperaturstigning, der er set over de sidste 100-150 år, sandsynligvis kan tilskrives naturlige variationer i klimaet, kan den betydelige globale opvarmning, der har præget de sidste 20-30 år, antageligt ikke forklares gennem de i dag

\section{Foraminiferer - gode klimaindikatorer}

Foraminiferer er mikroskopiske, encellede organismer, der tilhører gruppen Protozoa, og som er i familie med amøberne. Det er en meget vigtig gruppe af organismer, der i dag udgør en stor del af alt liv i verdenshavene. De ældste fossile foraminiferer er ca. 560 millioner år gamle, men gruppen har sandsynligvis eksisteret $\mathrm{i}$ ca. 1.000 millioner år og har været en meget succesfuld gruppe lige siden. Der kendes ca. 40.000 arter, hvoraf de ca. 10.000 er nulevende - resten er uddøde.

De fleste foraminiferer varierer i stør-

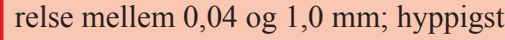
mellem $0,1 \mathrm{og} 0,5 \mathrm{~mm}$. De består af en

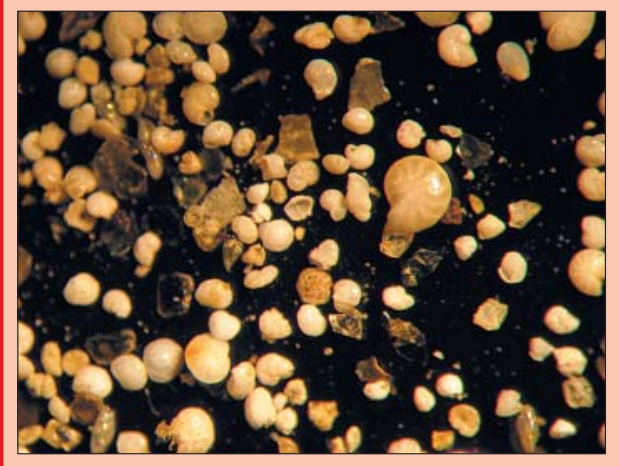

Fossil fauna fra Lille Istidsaflejring fra kerne 248260-2G fra Ameralik Fjord, Nuuk. (Foto: Marit-Solveig Seidenkrantz) slimet "krop" med slimtråde, der går ud fra kroppen, og som bruges til at opsamle eller indfange føde. Kroppen er normalt omsluttet af en skal af enten kalk eller sammenkittede sandskorn, som de har opsamlet fra havbunden. Det er denne skal, der bevares fossilt, og som man kan finde i jordlag langt tilbage i tiden.

Ud fra deres levevis kan foraminifererne inddeles i to hovedgrupper: De planktoniske, som lever frit svævende i vandsøjlen i de åbne oceaner, og de bundlevende (bentoniske), der lever på havbunden. De planktoniske foraminiferer lever overvejende af planteplankton eller mindre dyreplankton, som de fanger, mens de bundlevende foraminiferer også fortærer rester af døde dyr eller planter, der synker til bunds.

Foraminifererne udgør $2,5 \%$ af alle de arter af dyr, der har eksisteret gennem Jordens historie. Da der gennem tiden er opstået og igen forsvundet mange arter, bruges foraminiferer med sort held til aldersbestemmelse af jordlagene. De er desuden yderst nyttige til bestemmelse af tidligere tiders klima og miljø, idet de forskellige arter stiller forskellige krav til deres levested. De kan derfor bl.a. fortælle om havvandets temperatur, saltholdighed, strømmens styrke og mæng- den af ilt ved havbunden - for eksempel om der har været perioder med iltsvind. På den måde kan man lære, hvordan havstrømmene har løbet i tidligere tider, og hvordan det har påvirket klimaet. Da foraminifererne også er følsomme overfor forurening (fx organisk materiale, næringsstoffer og tungmetaller), bruges de også til at til undersøgelser af forurenede områder i havet.

De kalkskallede foraminiferer bygger desuden deres skal i kemisk ligevægt med havvandet. Det betyder, at man kan måle kemiske parametre såsom stabile ilt- og kulstofisotoper, hvilket igen giver information om havtemperatur, mængden af gletscheris, næringsforhold m.m.

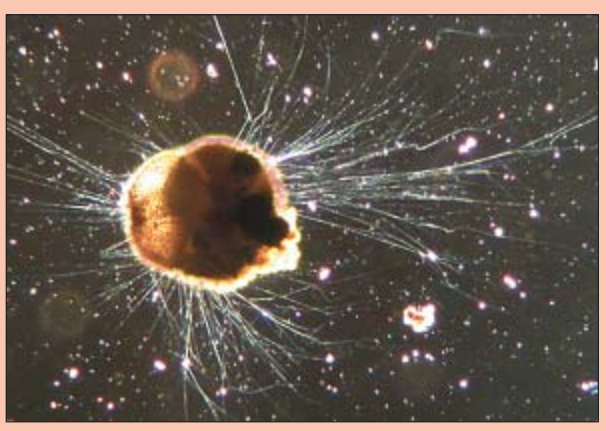

Levende foraminifer med slimtråde: Ammonia Tepida. (Foto: Scott Fay, UC Berkeley) 
A) Atmosfceretemperaturen i Europa gennem 2.000 år $i$ forhold til gennemsnittet for perioden 1961-1990. Kurven er baseret på en rakke geologiske data og angiver temperaturen som forskel til gennemsnittet for perioden 1961-1990 (kilde: Mann og Jones 2003, Geophys. Res. Lett.30). RoV: Romersk Varmtid, MMK: Mørke Middelalders Kuldeperiode; MiV: Middelalder Varmtid; LIT: Lille Istid; MO: Moderne Opvarmning. (Grafik: MaritSolveig Seidenkrantz)

B) Rekonstruktion af temperaturen (koldt Polart/varmt Atlantisk) af havvandet ud for Vestgrønland gennem de sidste 2000 år. Resultatet er baseret på forekomsten af forskellige arter af foraminiferer fra en sedimentkerne noer Nuuk. Disse data viser en opvarmning af vandet ud for Vestgrønland under perioder, hvor klimaet i Europa var koldere end $i$ dag, mens havvandet ved Vestgrønland var koldere end $i$ dag under perioder, hvor klimaet $i$ Europa var varmt. (Grafik: Marit-Solveig Seidenkrantz)

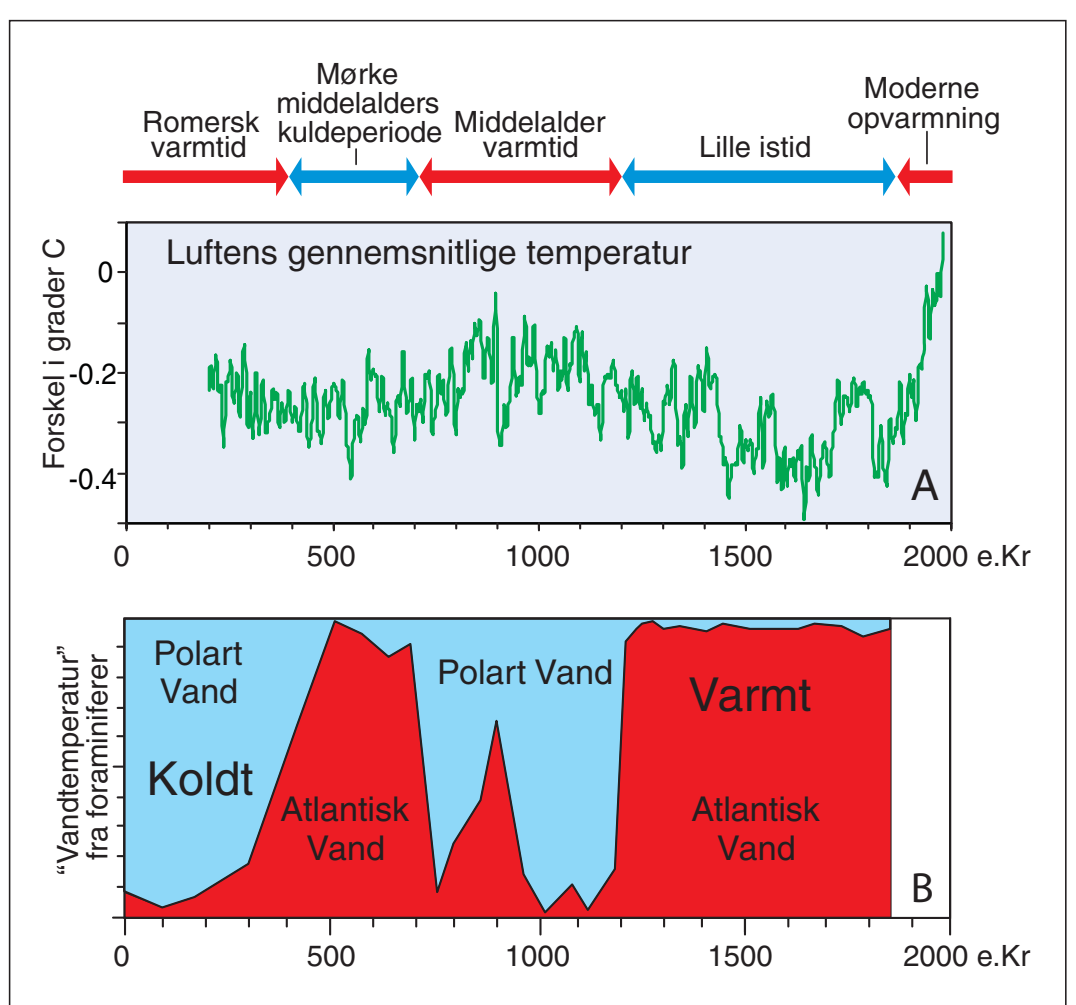

kendte naturlige processer. Dette tyder på, at udledningen af drivhusgasser er i gang med at foretage en fundamental ændring af hele klimasystemet.

Denne artikel har også varet bragt $i$ Aktuel Naturvidenskab nr. 5-2009.

\section{Reference:}

Seidenkrantz, M.-S., Kuijpers, A. \& Schmith, T. 2009. Comparing past and present climate? A tool to distinguish between natural and human-induced climate change. IOP Conference Series: Earth and Environmental Science.

\section{Kort nyt}

Gamma-glimt fra det unge univers Astronomer har observeret en enorm eksplosion i det unge univers. Sådanne gamma-strålingsglimt forekommer, når bestemte massive stjerner eksploderer. Det seneste gammastrålingsglimt fandt sted kun 630 millioner år efter Big Bang (altså for 13,1 milliarder år siden) og er det ældste gamma-glimt nogensinde observeret. Den tidligere rekord var 200 millioner år yngre. NASAs rumbaserede Swift-teleskop
Havtemperatur (juni måned) ved Fylla Banke, Vestgrønland, og lufttemperaturen om vinteren $i N V$ Europa i perioden 1950-2005. Bogstaverne A, $B$ og $C$ markerer perioder, hvor havets overflade-

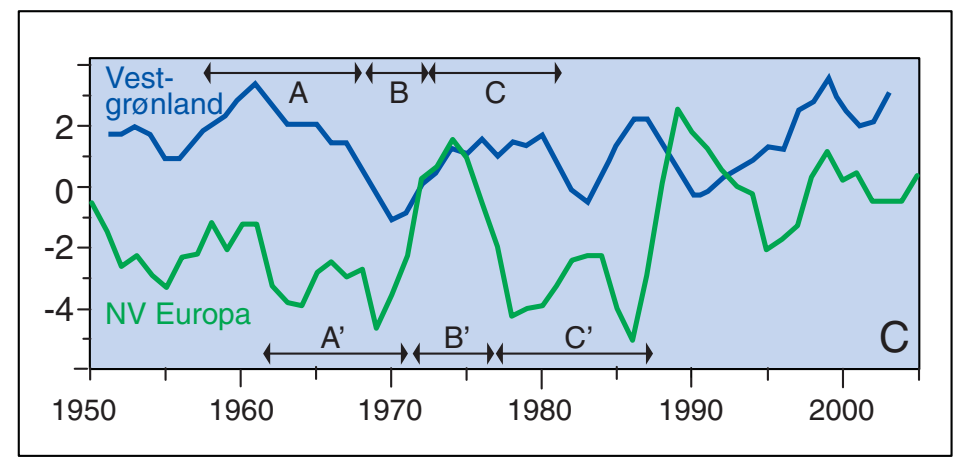
temperatur ved Vestgrønland var enten højere eller lavere end gennemsnitligt, mens $A$ ', $B$ 'og $C^{\prime}$ 'viser forsinkede og modsatrettede svingninger i temperaturen i NV-Europa. (Kilde: Danmarks Meteorologiske Institut og Northwest Atlantic Fisheries Organization, Canada) opdagede gamma-strålingsglimtet, kaldet GRB 090423, den 23. april i år og sendte automatisk besked til Jorden, hvor to hold astronomer rettede deres teleskoper i retning af gamma-strålingsglimtet. Astronomerne målte et rødskifte (negativt frekvensskifte) på 8,2 . Ud fra rødforskydningen af den elektromagnetiske stråling fra GRB 090423 kunne astronomerne beregne, at gammastrålingen var blevet udsendt for 13,1 milliarder år siden. Fordi universet udvider sig, for- skydes den elektromagnetiske stråling, som udsendes fra fjerne lyskilder, mod lavere frekvenser. Jo større afstanden er til et objekt, jo hurtigere fjerner det sig, og jo større bliver frekvensskiftet.

Dette er ikke blot en ny rekord, det er også et vindue til det tidlige univers. "Vi nærmer os nu tidspunktet for, hvornår vi tror de første galakser blev tændt", udtaler en af astronomerne

Nature news/JT 